\title{
Penggunaan Magnesium Sulfat untuk Menurunkan Angka Kejadian Cerebral Palsy pada Bayi Prematur
}

\author{
Herry Aktyar Matondang, Jusuf Sulaeman Effendi, Budi Handono, Andi Kurniadi \\ Departemen Obstetri dan Ginekologi Fakultas Kedokteran Universitas Padjadjaran \\ Rumah Sakit Dr. Hasan Sadikin Bandung \\ Korespondensi : Heri Aktyar Matondang, Email: matondang.dr@gmail.com
}

\begin{abstract}
Abstrak
Tujuan: Magnesium Sulfat merupakan senyawa kimia yang sudah banyak terbukti manfaatnya pada kehamilan. Selain digunakan sebagai obat anti kejang, dan obat tokolitik pada kontraksi prematur, magnesium sulfat berperan banyak pada proses intraseluler, diantaranya sebagai agen vasodilator pembuluh darah otak, menurunkan reaksi inflamasi, seperti sitokin dan zat radikal bebas, serta mencegah masuknya ion kalsium kedalam sel. Oleh karena itu, magnesium sulfat saat ini banyak digunakan sebagai agen neuroprotection. Prematuritas merupakan masalah serius karena hampir sebagian besar dari neonatus yang berhasil hidup akan mengalami kecacatan neurologis kongenital termasuk cerebral palsy (CP).

Metode: Penelitian ini merupakan jenis penelitian analitik korelatif dengan desain cross sectional. Pengumpulan data dilakukan pada periode April 2016-Maret 2017 melalui observasi data rekam medis. Subjek penelitian adalah pasien dengan diagnosa cerebral palsy yang melakukan pemeriksaan ke Rumah Sakit Hasan Sadikin Bandung, dengan riwayat lahir prematur. Pengambilan sampel menggunakan teknik accidental sampling dengan jumlah total sampel 94 pasien. Analisis data secara statistik menggunakan uji Chi-square.

Hasil: Dari 94 subjek penelitian, didapatkan angka kejadian cerebral palsy adalah 30(32\%), dengan tipe tersering adalah spastik. Kejadian cerebral palsy terjadi lebih tinggi secara bermakna pada subjek yang tidak mendapat pemberian magnesium sulfat $\left(\mathrm{MgSO}_{4}\right)$ dibandingkan dengan yang mendapatkan magnesium sulfat $\left(\mathrm{MgSO}_{4}\right)$ $(76,0 \%$ vs $23,3 \%, \mathrm{p}<0,05)$.

Kesimpulan: Terdapat hubungan yang signifikan dari pemberian magnesium sulfat pada ibu hamil terhadap angka kejadian cerebral palsy pada bayi prematur di Rumah Sakit Hasan Sadikin Bandung.
\end{abstract}

Kata kunci: magnesium sulfat, persalinan prematur, bayi prematur, cerebral palsy

\section{The used Magnesium Sulfate to Reduce Incidence of Cerebral Palsy in Premature Infants}

\begin{abstract}
Objective: Magnesium Sulfate is a chemical compound that has been widely used in pregnant women and has proven benefits to the condition of pregnancy. Magnesium has a beneficial effect on dead cells by decreasing proinflammatory or free radical cytokines that are formed during the process of reperfusion hypoxic-ischemia and inflammation processes, which in some cases occur in preterm delivery. Prematurity is a serious problem because most of the successful neonates will experience congenital neurological disability including cerebral palsy $(C P)$.

Methods: This research is a kind of analytic correlative research with cross sectional design. The data were collected during the period of medical record data April 2016-March 2017. The research subjects were pediatric patients with a diagnosis of cerebral palsy who performed the examination at Hasan Sadikin Hospital Bandung, with a history of premature birth. Samples were taken by purposive sampling technique with a total number of samples 94 patients. Statistical analysis using Chi-square statistical test.

Result: Of the 94 study subjects, the incidence rate of cerebral palsy was 30 (32\%), with the most common type being spastic. Cerebral palsy were significantly higher in subjects not receiving magnesium sulphate (MgSO4) compared with those receiving magnesium sulphate (MgSO4) (76.0\% vs 23.3\%, p <0.05).

Conclusion: There is a significant relationship between administration of magnesium sulfate in pregnant women and the incidence of cerebral palsy in premature infants at Hasan Sadikin Hospital Bandung.
\end{abstract}

Keywords: magnesium sulfate, preterm birth, premature infants, cerebral palsy 


\section{Pendahuluan}

Cerebral Palsy (CP) merupakan istilah yang digunakan untuk gangguan neurologik kronik yang bermanifestasi pada gangguan kontrol gerakan, yang muncul pada awal kehidupan, dengan latar belakang penyakit yang non progresif. Prevalensi CP di negara maju seperti Amerika berkisar pada angka 2 dari 1000 kelahiran bayi, sedangkan di negara berkembang insidensi CP masih berada pada angka yang lebih tinggi. Insidensi $\mathrm{CP}$ di Indonesia masih belum dapat dikaji secara pasti dan berkala, namun menurut Soetjiningsih tahun 1995, angka kejadian CP diperkirakan rata-rata 5 dari 1000 kelahiran bayi yang ada. ${ }^{1,2}$

Resiko kejadian CP cenderung meningkat dikaitkan dengan usia kehamilan, dengan insidensi 30\%-50\% anak dengan diagnosa CP terlahir prematur. WHO menetapkan bahwa kelahiran prematur merupakan kelahiran yang terjadi kurang dari 37 minggu masa kehamilan, atau kurang dari 259 hari sejak hari pertama haid terakhir pada wanita. Persalinan prematur terjadi sebanyak $11,1 \%$ dari kelahiran total di seluruh dunia. ${ }^{1,3,4}$ Di Amerika Serikat terjadi angka kelahiran prematur sebanyak $12 \%$ dari seluruh total kelahiran di negara tersebut. Di Indonesia, angka kelahiran bayi dengan kondisi kehamilan $<37$ minggu tercatat terjadi 15 dari 100 kelahiran bayi. Sebesar 25\%-50\% kasus persalinan preterm menyebabkan gangguan neurologi jangka panjang. 5,6

Prevalensi CP tercatat berbanding terbalik dengan usia kehamilan, semakin besar usia kehamilan maka semakin kecil resiko CP yang akan terjadi. Himpens et al, 2008 mendeskripsikan hasil penelitiannya sebagai berikut $14,6 \%$ kejadian $\mathrm{CP}$ pada kelahiran prematur 22-27 minggu; $6,2 \%$ pada kelahiran prematur 28-31 minggu; $1,7 \%$ pada kelahiran prematur 32-36 minggu; dan 0,1\% pada kelahiran cukup bulan.,
Prevalensi CP secara global berkisar antara 1-1,5 per 1000 kelahiran hidup, dengan insidensi meningkat pada kelahiran prematur. Di negara maju prevalensi CP dilaporkan 2-2,5 kasus per 1000 kelahiran hidup, sedangkan di negara berkembang berkisar antara 1,5-5,6 kasus per 1000 kelahiran hidup. Hingga saat ini belum tersedia data akurat perihal jumlah penderita $\mathrm{CP}$ di Indonesia, diperkirakan terdapat sekitar 1-5 kasus per 1000 kelahiran hidup.,

Kejadian CP dan gangguan kognitif berhubungan dengan kerusakan peri ventrikuler white matter. Hal ini sering ditemui pada bayi yang dilahirkan sebelum usia kehamilan 32 minggu. Sitokin pro inflamasi telah di ketahui secara signifikan meningkat pada cairan amnion dan otak janin neonatus dengan infeksi dan yang disertai CP. Infeksi ke dalam cairan amnion dapat menimbulkan persalinan prematur dan dapat pula menyebabkan infeksi pada janin. Mikroorganisme menghasilkan produk yang dapat memicu sel mononuclear menghasilkan IL-1 dan TNF- $\alpha$, yang dapat meningkatkan permeabilitas sawar darah otak (blood brain barrier) sehingga produk mikroorganisme dan sitokin pro inflamasi tersebut dapat masuk ke otak dan menimbulkan kerusakan pada jaringan putih otak (White Matter Damage) janin, oleh karena itu dibutuhkan neuroproteksi yang tepat untuk melindungi otak janin dari kerusakan yang terjadi. ${ }^{9-11}$

Lesi patologi yang paling sering terjadi yang berhubungan dengan Cerebral Palsy pada bayi prematur adalah Periventrikular White Matter Injury (PWMI). Oligodendrosit berkumpul paling banyak pada glia di White Matter otak. N-methyl-D-aspartic acid (NMDA) reseptor pada oligodendrosit menjadi sangat penting didalam proses kerusakan pada Glia. N-methyl-D-aspartic acid (NMDA) reseptor antagonis menjadi agen neuroprotektif yg potensial untuk kerusakan otak janin dalam kehamilan. ${ }^{11}$

Intervensi antenatal dapat menjadi 
langkah pencegahan ataupun penurunan angka kejadian kelahiran bayi dengan diagnosa CP. Kondisi kelahiran prematur biasanya disertai dengan kondisi berat bayi lahir rendah, yang dikaitkan dengan kurangnya asupan suplemen magnesium pada saat ibu hamil. Salah satu suplemen magnesium yang sering digunakan dalam bidang obstetri adalah Magnesium Sulfat $\left(\mathrm{MgSO}_{4}\right) .{ }^{12,13}$

Pada beberapa dekade terdahulu, $\mathrm{MgSO}_{4}$ telah banyak diteliti pengaruhnya terhadap demineralisasi tulang fetus, serta digunakan sebagai suplemen pada pasien preeklamsia dan agen tokolisis pada persalinan prematur. Dalam perkembangannya $\mathrm{MgSO}_{4}$ juga mulai diteliti pengaruhnya terhadap proteksi neurogenik dalam proses kehamilan. Magnesium sulfat berperan pada proses intraseluler, diantaranya sebagai agen vasodilator pembuluh darah otak, menurunkan reaksi inflamasi, seperti sitokin dan zat radikal bebas, serta mencegah masuknya ion kalsium kedalam sel. , $14^{14}$

Pada tahun 1995, Nelson dan Grether mempublikasikan hasil penelitian $\mathrm{MgSO}_{4}$ sebagai agen neuroprotektor untuk pertama kalinya. Hasil penelitian tersebut menggambarkan bahwa lebih dari 50\% bayi lahir prematur $(\mathrm{BB}<1500 \mathrm{gr})$ dengan diagnosa $\mathrm{CP}$ dapat bertahan hingga tiga tahun dibandingkan kelompok lainnya yang tidak mendapat suplemen $\mathrm{MgSO}_{4} \cdot{ }^{14}$

Angka kejadian CP pada kelahiran prematur menjadi permasalahan dalam bidang obstetri yang membutuhkan strategi baru untuk mengurangi insidensinya. Peran $\mathrm{MgSO}_{4}$ sebagai neuroprotektor dapat diteliti lebih lanjut efeknya terhadap pencegahan CP. Dalam artikel ini akan dibahas dan dideskripsikan bagaimana hubungan pemberian $\mathrm{MgSO}_{4}$ pada ibu hamil terhadap angka kejadian cerebral palsy pada bayi lahir prematur di Rumah Sakit Hasan Sadikin Bandung.

\section{Metode}

Penelitian ini merupakan jenis penelitian analitik korelatif dengan desain penelitian cross-sectional. Jenis penelitian deskriptif korelatif merupakan penelitian yang mendeskripsikan dan menggambarkan suatu fenomena hubungan antar variabel yang diangkat. Jenis penelitian analitik korelatif digunakan dalam penelitian ini dengan tujuan untuk mengetahui ada tidaknya hubungan antara variabel independen dan variabel dependennya.

Dalam penelitian ini, variabel independennyamerupakan riwayat pemberian Magnesium Sulfat $\left(\mathrm{MgSO}_{4}\right)$ pada ibu hamil dengan anak cerebral palsy, sedangkan variabel dependennya merupakan anak lahir prematur dengan diagnosa cerebral palsy. Desain penelitian menggunakan metode pendekatan waktu cross-sectional. Subjek penelitian ditetapkan dan analisis dalam satu waktu.

Instrumen penelitian yang digunakan dalam penelitian ini merupakan sumber data sekunder yang berasal dari data rekam medis subjek penelitian. Dari data rekam medis akan dianalisis secara retrospektif mengenai riwayat pemberian $\mathrm{MgSO}_{4}$ pada ibu saat kehamilan sedang berlangsung.

Populasi penelitian ini adalah anak penderita cerebral palsy yang datang untuk melakukan pemeriksaan di RSHS pada periode bulan November 2016 sampai dengan April 2017. Sampel penelitian merupakan bagian dari populasi penelitian yang memenuhi kriteria inklusi dan ekslusi yang telah ditetapkan.

Pengambilan sampel menggunakan teknik purposive sampling, sehingga jumlah sampel penelitian ditentukan dengan menggunakan rumus Slovin dengan hasil 94 pasien.

Pemilihan subjek pada penelitian ini harus memenuhi kriteria inklusi dan tidak termasuk dalam kriteria eksklusi. Kriteria 
inklusinya adalah pasien anak dengan riwayat lahir premature, melakukan pemeriksaan di RSHS antara periode Bulan November 2016 sampai dengan April 2017. Sedangkan kriteria eksklusinya adalah bayi lahir aterm atau cukup bulan, bayi lahir dengan cacat bawaan, kelahiran bayi kembar, tidak memiliki data rekam medis yang lengkap.

Analisa univariat dalam penelitian melalui persentase dan distrubusi frekuensi kejadian, sedangkan analisa bivariat menggunakan uji Chi-square untuk mengetahui hubungan antara pemberian $\mathrm{MgSO}_{4}$ pada ibu hamil dengan angka kejadian cerebral palsy pada bayi lahir prematur. Pengujian hipotesis diawali dengan penetapan Ho penelitian terlebih dahulu.

$\mathrm{Ho}=$ tidak terdapat hubungan pemberian $\mathrm{MgSO}_{4}$ pada ibu hamil terhadap angka kejadian cerebral palsy pada bayi lahir prematur. Ketentuan uji hipotesis, adalah:

Ho diterima bila Sig.t $>\alpha$, dengan $\boldsymbol{\alpha}=0,05$

Ho ditolak bila Sig.t $<\alpha$, dengan $\boldsymbol{\alpha}=0,05$

\section{Hasil}

Berdasarkan kelompok usia kehamilan, maka dapat diketahui distribusi karakteristik subjek penelitian pada tabel 1 .
Pada tabel 1 tampak bahwa rerata usia ibu yang mendapat $\mathrm{MgSO} 4$ adalah $26 \pm 4,3$ tahun, dan yang tidak mendapat $\mathrm{MgSO} 4$ adalah $25 \pm 4,7$ tahun. Rerata usia kehamilan subjek penelitian yang mendapat $\mathrm{MgSO} 4$ adalah $32,6 \pm 2,0$ minggu, dan yang tidak mendapat $\mathrm{MgSO} 4$ adalah 32,4 $\pm 2,2$ minggu. Rerata berat badan lahir bayi yang mendapat MgSO4 adalah 1910,2 \pm 390,1 gram, dan yang tidak mendapat $\mathrm{MgSO} 4$ adalah 1871 $\pm 392,9$ gram. Kejadian cerebral palsy pada bayi didapatkan 7 kasus pada subjek penelitian yang mendapat $\mathrm{MgSO} 4$, dan 23 kasus pada subjek penelitian yang tidak mendapat $\mathrm{MgSO} 4$.

Pada tabel 2 menunjukkan bahwa angka kejadian cerebral palsy meningkat pada bayi yang lahir tanpa mendapat pemberian $\mathrm{MgSO} 4$ sebanyak 23 pasien, dan menurun pada bayi yang lahir mendapat $\mathrm{MgSO} 4$ sebelumnya, sebanyak 7 pasien. Dengan melakukan analisis data didapatkan nilai odd ratio 9,9 yang menunjukkan bahwa kejadian cerebral palsy terjadi lebih tinggi secara bermakna pada subjek yang tidak mendapat pemberian magnesium sulfat.

\section{Tabel 1 Karakteristik Subjek Penelitian}

\begin{tabular}{lcc}
\hline \multirow{2}{*}{ Variabel } & \multicolumn{2}{c}{ Kelompok } \\
\cline { 2 - 3 } & $\begin{array}{c}\text { Mendapat MgSO4 } \\
\mathrm{N}=55\end{array}$ & $\begin{array}{c}\text { Tidak mendapat MgSO4 } \\
\text { N=39 }\end{array}$ \\
\hline Usia ibu & $26(4,3)$ & $25(4,7)$ \\
Rerata (simpang baku) & & \\
Usia kehamilan & $32,6(2,0)$ & $32,4(2,2)$ \\
Rerata (simpang baku) & & \\
Berat lahir bayi (gram) & $1910,2(390,1)$ & $1871(392,9)$ \\
Rerata (simpang baku) & & \\
Kejadian Cerebral Palsy & 7 & 23 \\
Ada & 48 & - \\
Tidak ada & & - \\
Jenis Cerebral Palsy & 6 & - \\
Hipotonik & 22 & \\
Spastik & 2 & \\
Ataksik & & \\
\hline
\end{tabular}


Tabel 2 Perbandingan Angka Kejadian Cerebral Palsy pada Kelompok yang Mendapat MgSO4, dibandingkan dengan yang Tidak Mendapat MgSO4

\begin{tabular}{rcccccc}
\hline \multirow{2}{*}{ Kejadian } & & \multicolumn{2}{c}{ Kelompok } & & \\
\cline { 3 - 5 } & & $\begin{array}{c}\text { Mendapat } \\
\text { MgSO4 }\end{array}$ & $\begin{array}{c}\text { Tidak mendapat } \\
\text { MgSO4 }\end{array}$ & $\mathbf{X}^{2}$ & p-value * \\
\hline \multirow{2}{*}{ Cerebral Palsy } & Ada & 7 & 23 & & \\
& Tidak ada & 48 & 16 & 22,5 & 0,0001 \\
Total & & 55 & 39 & & \\
\hline
\end{tabular}

*Uji Chi Square

\section{Pembahasan}

Hasil analisis statistik uji Chisquare untuk melihat hubungan pemberian magnesium sulfat pada ibu hamil terhadap angka kejadian cerebral palsy pada bayi lahir prematur di Rumah Sakit Hasan Sadikin Bandung diperoleh nilai Odds Ratio (OR) sebesar 9,9 dan p-value sebesar 0,0001 lebih kecil dari nilai $\alpha ́(0,05)$. Hasil penelitian ini dapat diartikan bahwa terdapat hubungan yang signifikan antara pemberian magnesium sulfat pada ibu hamil terhadap angka kejadian cerebral palsy pada bayi lahir prematur. Hal ini sesuai dengan beberapa hasil penelitian sebelumnya yang telah dilakukan, dimana magnesium sulfat memberikan pengaruh terhadap proteksi neurogenik dalam proses kehamilan yang berperan pada proses intraseluler, diantaranya sebagai agen vasodilator pembuluh darah otak, menurunkan reaksi inflamasi, seperti sitokin dan zat radikal bebas, serta mencegah masuknya ion kalsium kedalam sel sehingga mencegah terjadinya kerusakan otak khususnya pada periventrikular white matter Injury (PWMI).

Berdasarkan hasil penelitian yang telah dilakukan dan setelah dilakukan analisis statistik dapat disimpulkan bahwa pemberian magnesium sulfat pada ibu hamil sebelum terjadinya kelahiran bayi prematur, dapat diberikan sebagai agen neuroprotector untuk mencegah kejadian cerebral palsy pada perkembangan bayi selanjutnya. Simpulan pemberian magnesium sulfat (MgSO4) sebagai neuroprotector atau lebih dikenal dengan brain protector memiliki efek yang positif bila diberikan pada ibu hamil yang beresiko terjadinya persalinan premature dalam mencegah terjadinya kejadian cerebral palsy pada anak yang dilahirkan.

\section{Daftar Pustaka}

1. Bouet P-E, Brun S, Madar H, Baisson A-L. Implementation of an antenatal magnesium sulfate protocol for fetal neuroprotection in preterm infants. Scientific Reports. 2015;5(14732):1-8.

2. Soetjiningsih. Tumbuh Kembang Anak I. Jakarta: Buku Kedokteran EGC; 1995.

3. Yang S, Li W, Challis JR. Probiotic Lactobacillus rhamnosus GR-1 supernatant prevents lipopolysaccharideinduced preterm birth and reduces inflammation in pregnant CD-1 mice. American Journal Obstetrics and Gynecology. 2014;211(1):1-12.

4. Blencowe H, Cousens S, Oestergaard MZ. National, regional, and worldwide estimates of preterm birth rates in the year 2010 with time trends since 1990 for selected countries: a systematic analysis and implications. Lancet. 2012;379:2162-72.

5. Sulistiarini D, Berliana SM. Faktor-faktor yang memengaruhi kelahiran prematur di Indonesia: analisa data riskesdas 2013 
3. E-Journal WIDYA Kesehatan Dan Lingkungan. 2016;1(2):109-15.

6. Management of preterm labor: American college of obetetrician and gunecologist. Obstetric and Gynecology. 2012;119(6):1308-17.

7. Oskoui M, Coutinho F, Dykeman J. An update on the prevalence of cerebral palsy: a systematic review and metaanalysis. Developmental Medicine \& Child Neurology. 2013;55(6):509-19.

8. Himpens E, Broeck Vd, Oostra A. Prevalence, type, distribution, and severity of cerebral palsy in relation to gestational age: a meta-analytic review. Dev Med Child Neurol. 2008;50:33440.

9. McAdams RM, Juul SE. Cerebral palsy: prevalence, predictability, and prenatal consulting. Neureview. 2011;12(10):56472.

10. Dabydeen L. Cerebral palsy: A neonatal perspective. Annal of Indian Academy of Neurology. 2007;10:33-43.
11. Peebles D, Kenyon AP. Magnesium sulphate to prevent cerebral palsy following preterm birth. Opinion Paper Scientific Impact Paper. 2011;29:1-7.

12. Mcintyre S, taitz D, Keogh J. A systematic review of risk factors for cerebral palsy in children born at term in developed countries. Developmental Medicine \& Child Neurology. 2013;55(6):499-508.

13. Conde-Agudelo A, Romero R. Antenatal magnesium sulfate for the prevention of cerebral palsy in preterm infants less than 34 weeks' gestation: a systematic review and metaanalysis. American Journal of Obstetrics and Gynecology. 2009:595609.

14. Nelson KB, Grether JK. Can magnesium sulfate reduce the risk of cerebral palsy in very low birthweight infants? Pediatrics. 1995;95(2):263-9.

15. Magnesium sulfate use in obstetrics. Commiterr Opinion The American College of Obstetricians and Gynecologists. 2016;652:1-2. 